\title{
Alkaloids from the Chinese Vine Gnetum montanum
}

Frédéric Martin, Melissa L. Sykes, Todd Shelper, Vicky M. Avery, David Camp, Ronald J. Quinn** and Rohan A. Davis

Eskitis Institute, Griffith University, Brisbane, QLD 4111, Australia

${ }^{*}$ To whom correspondence should be addressed. Tel. +61-7-3735-6000. Fax: +61-7-3735-6001. E-mail: r.quinn@griffith.edu.au. 
During a high-throughput screening campaign of a prefractionated natural product library, fractions prepared from the Chinese vine Gnetum montanum (Gnetaceae) showed in vitro activity against Pseudomonas aeruginosa wild type strain PAO1. UV-directed isolation of the organic extract from the leaves resulted in the purification of the TFA salts of the new natural products $N$ methyl-laudanosolinium (1), 3'-hydroxy- $N, N$-dimethyl coclaurinium (2), 1,9,10-trihydroxy-2methoxy-6-methyl aporphinium (3) and 6a,7-didehydro-1,9,10-trihydroxy-2-methoxy-6-methyl aporphinium (4). Compound 4 is described here for the first time, and this is the first report of compounds 1-3 as natural products. We also report the known natural products latifolian A (5) and magnocurarine (6). When tested for their effect on the viability of this bacterial strain, $\mathbf{5}$ displayed an $\mathrm{IC}_{50}$ value of $9.8 \mu \mathrm{M}$, while $\mathbf{3}$ and $\mathbf{4}$ displayed minimal activity, and $\mathbf{1 ,} \mathbf{2}$ and $\mathbf{6}$ were inactive. Based upon a 55\% inhibitory activity displayed against Staphylococcus aureus culture at $350 \mu \mathrm{M}$ of compound, $\mathbf{5}$ was estimated to have a moderate selectivity index to P.aeruginosa of 36 times. 
Species that comprise the group of non-fermenting, Gram-negative bacteria, pose a major risk for healthcare as they possess multidrug resistance. ${ }^{1}$ Such species include $P$. aeruginosa, $S$. maltophilia, and Acinetobacter spp, which are opportunistic pathogens and prominent in critically ill, hospitalised patients. ${ }^{2}$ The multidrug, genetically acquired resistance of these pathogens is primarily due to the active transport of drugs out of the cell by multidrug transporters in efflux pump systems. ${ }^{3,4}$ Intrinsic resistance by these bacteria also decreases those antibiotics that can be used for treatment, including ampicillin, cephalosporins and macrolide antibiotics, mainly due to impermeability. ${ }^{1,5}$ Because of resistance displayed by these and other, particularly Gram-negative bacteria, there has been further reliance upon more toxic drugs than those commonly applied. ${ }^{6}$ These facts highlight the urgent need to discover new, selective antibiotics, with low toxicity and new mechanisms of action. Natural products constitute a possible source of new leads for this search as most existing antibiotics are based on natural chemotypes. ${ }^{7}$

We undertook a high throughput screening (HTS) campaign to identify potential leads with an antibiotic effect against the wild type strain of $P$. aeruginosa (PAO1). Initial hits were identified in an in vitro, whole cell, optical density based 384 well survival assay. The $P$. aeruginosa efflux pump knockout strain, PAO200 (MexAB-OprM deficient mutant) was employed to screen a prefractionated natural product library, this strain was used to potentially increase the initial hits identified by decreasing efflux clearance. HTS hits were re-tested against the wild type strain PAO1 and a Gram-positive bacterium, Staphylococcus aureus (strain 01A1095) for estimation of Gram selectivity. Three fractions prepared from the Chinese plant Gnetum montanum Markgr. showed in vitro activity against $P$. aeruginosa PAO200. These fractions were early eluting ones and showed characteristic UV profiles. Thus, compounds with a short retention time obtained from a chromatographical separation of the combined $\mathrm{CH}_{2} \mathrm{Cl}_{2} / \mathrm{MeOH}$ plant extract were isolated. This afforded the benzylisoquinoline alkaloids $N$-methyl-laudanosolinium (1), and 3'-hydroxy- $N, N$ dimethyl coclaurinium (2), the aporphine alkaloids 1,9,10-trihydroxy-2-methoxy-6-methyl 
aporphinium (3) and 6a,7-didehydro-1,9,10-trihydroxy-2-methoxy-6-methyl aporphinium (4), as well as the known alkaloids latifolian A (5) and magnocurarine (6). The antibacterial activities for compounds 1-6 against $P$. aeruginosa PAO1 and S.aureus 01A1095 are also reported.

\section{Result and discussion}

The air-dried and ground leaves of G. montanum were sequentially extracted with $n$ hexane, $\mathrm{CH}_{2} \mathrm{Cl}_{2}$, and $\mathrm{MeOH}$. The $n$-hexane extract was discarded, and the remaining organic extracts combined and prepurified on polyamide gel using $\mathrm{MeOH}$ as eluent. The resulting crude $\mathrm{MeOH}$ wash was subjected to several steps of $\mathrm{C}_{18}$ semi-preparative HPLC with different gradients of $\mathrm{MeOH} / \mathrm{H}_{2} \mathrm{O}(0.1 \%$ TFA) to yield 1 (6.1 mg, 0.24\% dry wt), 2 (7.2 mg, 0.17\% dry wt), 3 (6.3 mg, 0.15\% dry wt), 4 (1.3 mg, 0.03\% dry wt), 5 (3.6 mg, 0.09\% dry wt) and 6 (6.4 mg, 0.15\% dry wt). All alkaloids were isolated as their TFA salts. Compounds $\mathbf{5}$ and $\mathbf{6}$ were assigned to known compounds latifolian A and magnocurarine ${ }^{8}$, respectively, after spectroscopic data comparison. Latifolian A was previously isolated from Gnetum latifolium ${ }^{9}$ and exhibited inhibition in an assay against the JNK3 kinase. Magnocurarine, isolated from a variety of plants, has been shown to display weak antinociceptive activity. ${ }^{10}$

Compound 1 was isolated as an optically active brown gum. Its molecular formula was shown to be $\mathrm{C}_{18} \mathrm{H}_{22} \mathrm{NO}_{4}{ }^{+}$by HRESIMS ([M] $]^{+}: m / z$ 316.15437). Analysis of the ${ }^{1} \mathrm{H} \mathrm{NMR}$ and gCOSY spectra (Table 1) revealed the presence of two aromatic isolated singlets at $\delta_{\mathrm{H}} 6.58$ and 5.94, one aromatic ABX system $\left(\delta_{\mathrm{H}} 6.65, \mathrm{~d}, J=8.0 \mathrm{~Hz} ; \delta_{\mathrm{H}} 6.53, \mathrm{~d}, J=1.9 \mathrm{~Hz}\right.$; and $\delta_{\mathrm{H}} 6.35, \mathrm{dd}, J$ $=8.0,1.9 \mathrm{~Hz})$, two $\mathrm{N}^{+} \mathrm{Me}$ groups $\left(\delta_{\mathrm{H}} 3.23\right.$ and 3.03$)$, two contiguous methylene groups $\left(\delta_{\mathrm{H}}\right.$ 3.68/3.54 and 2.97) and finally one methine-methylene system $\left(\delta_{\mathrm{H}} 4.55 / 3.44,2.68\right)$. Furthermore, correlations observed in the gHSQC and gHMBC spectra showed the presence of two different substituted aromatic rings (rings A and B), both of which possessed a catechol function $\left[\delta_{\mathrm{C}} 143.6\right.$ 
and 145.5 (first ring), 145.2 and 144.1 (second ring)]. The two isolated aromatic singlets were found to be para to each other on the aromatic ring $\mathrm{A}$ ( $\delta_{\mathrm{C}} 114.7$ and 114.5 respectively), while the aromatic protons in the $\mathrm{ABX}$ system could be placed on the aromatic ring $\mathrm{B}\left(\delta_{\mathrm{C}} 115.2,116.6\right.$ and 119.9). The two last carbons belonging to the aromatic ring A were quaternary $\left(\delta_{\mathrm{C}} 118.9\right.$ and 121.6). The carbon at $\delta_{\mathrm{C}} 118.9$ showed HMBC correlations with the two contiguous methylenes (with carbons at $\delta_{\mathrm{C}} 54.3$ and 22.4), while the carbon at $\delta_{\mathrm{C}} 121.6$ displayed HMBC correlations with the methine-methylene system (with carbons at $\delta_{\mathrm{C}} 71.3,35.6$ ). Moreover the protons in both $\mathrm{N}^{+} \mathrm{Me}$ groups showed HMBC correlations with the carbons at $\delta_{\mathrm{C}} 71.3$ and 54.3, thus allowing the ring to be closed, creating an isoquinolinium moiety. Furthermore, correlations between the carbon at $\delta_{\mathrm{C}}$ 35.6, present in the methine-methylene system, with protons belonging to the aromatic ring $\mathrm{B}$ confirmed that 1 was a benzylisoquinoline derivative. These two systems were connected through a quaternary carbon at $\delta_{\mathrm{C}}$ 127.7. Compound $\mathbf{1}$ is thus $N$-methyl-laudanosolinium trifluoroacetate. The synthetic preparation of the iodide salt has already been reported. ${ }^{11}$ We report here the full NMR characterisation of $\mathbf{1}$.

In order to determine the absolute stereochemistry of (+)-1 we compared the optical rotation data for $(+)-N$-methyl-laudanosolinium with literature values of related natural products, such as $(+)$-roefractine, ${ }^{12}(+)$-laudanosine ${ }^{13}$ and $(+)$-reticuline ${ }^{14}$ whose absolute stereochemistry had been unequivocally determined, either by CD measurements, or by asymmetrical synthesis. These three compounds all showed positive optical rotations, and their absolute configuration at C-1 was determined as $S$. The optical rotation of compound 1 was also positive, thus suggesting that it shares the same absolute stereochemistry $(S)$ as $(+)$-roefractine, $(+)$-laudanosine and $(+)$ reticuline.

The major metabolite, compound $\mathbf{2}$, was isolated as an optically active gum. Comparison of the NMR and UV data of $\mathbf{2}$ with $\mathbf{1}$ clearly identified that $\mathbf{2}$ also belonged to the benzylisoquinoline structure class. The major difference in the NMR data of $\mathbf{1}$ with $\mathbf{2}$ was that one 
of the phenolic moiety present had been replaced by a methoxy group in $2\left(\delta_{\mathrm{H}} 3.75 / \delta_{\mathrm{C}} 55.1\right)$. This was confirmed by the HRESIMS $\left([\mathrm{M}]^{+}: \mathrm{m} / \mathrm{z} 330.16914\right)$ which indicated a molecular formula of $\mathrm{C}_{19} \mathrm{H}_{24} \mathrm{NO}_{4}{ }^{+}$, consistent with $\mathbf{2}$ being a methyl ether derivative of $\mathbf{1}$. The methoxy position was determined following gHMBC analysis. A strong correlation could be observed between the methoxy protons and the carbon C-6 $\left(\delta_{\mathrm{C}} 147.7\right)$. Moreover the ROESY spectrum showed strong correlation between the methoxy protons and the aromatic proton $\mathrm{H}-5\left(\delta_{\mathrm{H}} 6.79\right)$. The structure of compound 2 was therefore assigned as the trifluoroacetate salt of 3 '-hydroxy- $N, N$-dimethylcoclaurinium. This is the first report of $\mathbf{2}$ as natural product. As for compound $\mathbf{1}$, the synthesis of 2 has been previously reported. ${ }^{15}$ Our data is in accordance with the UV spectrum of the literature. Moreover we report here the full NMR data of 2.

The absolute configuration of $\mathrm{C}-1$ of 2 could be determined using the same arguments as for that of $\mathbf{1}$. Since the optical rotation of $\mathbf{2}$ was also positive, the configuration of C-1 was assigned as $S$.

Compound $\mathbf{3}$ was isolated as an optically active gum. Its UV spectrum was markedly different compared to $\mathbf{1}$ and $\mathbf{2}$. Moreover, the molecular formula obtained from the HRESIMS $\left([\mathrm{M}]^{+}: m / z 328.15320\right), \mathrm{C}_{19} \mathrm{H}_{22} \mathrm{NO}_{4}{ }^{+}$, indicated that $\mathbf{3}$ is a reduced form of $\mathbf{2}$, the plausible structure being an aporphine derivative. Analysis of the ${ }^{1} \mathrm{H}$ NMR spectrum (Table 2) showed three aromatic singlets at $\delta_{\mathrm{H}} 7.85,6.78$ and 6.71 , but signals were still present for both the two contiguous methylenes $\left(\delta_{\mathrm{H}} 3.74 / 3.65\right.$ and $\left.3.18 / 2.93\right)$, the methine-methylene system $\left(\delta_{\mathrm{H}} 4.56 / 3.16,2.73\right)$, the two $\mathrm{N}^{+}$Me groups $\left(\delta_{\mathrm{H}} 3.34\right.$ and 2.93$)$ and the methoxy group $\left(\delta_{\mathrm{H}} 3.85\right)$. These signals are typical for aporphine derivatives ${ }^{16}$ and aporphinium salts. ${ }^{17}$ The correlations observed in the gHSQC and gHMBC spectra confirmed the structure. The isolated singlet at $\delta_{\mathrm{H}} 6.78\left(\delta_{\mathrm{C}} 109.0\right)$ was attached to the aromatic ring A. HMBC correlations were observed from this signal to two phenolic carbons $\left(\delta_{\mathrm{C}} 148.1\right.$ and 142.1$)$ and a quaternary aromatic carbon at $\delta_{\mathrm{C}} 119.5$. The carbon at $\delta_{\mathrm{C}} 119.5$ showed $\mathrm{HMBC}$ correlations to both contiguous methylene protons (with carbons at $\delta_{\mathrm{C}} 23.1$ and 60.4) as 
well as the methine-methylene system with carbons at $\delta_{\mathrm{C}} 68.3$ and 28.1 . The carbon at $\delta_{\mathrm{C}} 28.1$ also displayed correlations with the two other aromatic proton singlets belonging to the aromatic ring B. With the help of the gHMBC spectrum, the four other remaining carbons could be determined to be two phenolic carbons in ortho position to each other $\left(\delta_{C} 144.6\right.$ and 143.7$)$ and two quaternary carbons $\left(\delta_{\mathrm{C}} 123.4\right.$ and 122.5$)$. Finally the aromatic proton at $\delta_{\mathrm{H}} 7.85$ displayed a correlation with a quaternary carbon at $\delta_{\mathrm{C}} 120.4$, which belongs to the aromatic ring $\mathrm{A}$, validating the aporphine skeleton. The methoxy group of $\mathbf{3}$ was positioned at C-2 following 2D NMR data analysis. The methoxy protons $\left(\delta_{\mathrm{H}} 3.85\right)$ showed a strong HMBC correlation with the $\mathrm{C}-2$ phenolic carbon $\left(\delta_{\mathrm{C}}\right.$ $148.1)$ and showed a ROESY correlation to the aromatic proton $\mathrm{H}-3\left(\delta_{\mathrm{H}} 6.78\right)$. Compound 3 is thus the trifluoroacetate salt of 1,9,10-trihydroxy-2-methoxy-6-methyl aporphinium, This is the first report of $\mathbf{3}$ as a natural product. Its synthesis has been reported by the same group as that of of $\mathbf{2}^{15}$, this latter structure being the starting point to get 3 by oxidative coupling. Our data is in accordance with the ${ }^{1} \mathrm{H}$ NMR and UV spectra from the literature. Moreover we report here the full ${ }^{13} \mathrm{C}$ NMR data of 2

To determine the absolute stereochemistry of $(+)-\mathbf{3}$ we compared the optical rotation data with literature values of different aporphines, which have been summarised by Ringdahl et al. ${ }^{18}$. They reported values from a set of these alkaloids whose absolute stereochemistry had been unequivocally determined by CD measurements. Furthermore the compounds which showed positive optical rotations were determined to have an absolute configuration of $S$ at C-6a. Since the optical rotation of compound $\mathbf{3}$ was positive, we assigned the C-6a absolute stereochemistry as $S$.

The minor plant metabolite, $\mathbf{4}$, was isolated as an optically inactive gum. Its molecular formula of $4\left(\mathrm{C}_{19} \mathrm{H}_{20} \mathrm{NO}_{4}{ }^{+}\right)$, given by HRESIMS ([M] $\left.]^{+}: m / z 326.13819\right)$, is only different from that of $\mathbf{3}$ by the loss of two hydrogens, which indicated that $\mathbf{4}$ was a reduced form of $\mathbf{3}$. On analysing the ${ }^{1} \mathrm{H}$ NMR spectrum of 4 (Table 2), the disappearance of the signals belonging to the methine- 
methylene system became evident. The aromatic part of the spectrum also showed major modifications. Four aromatic singlets could be detected $\left(\delta_{\mathrm{H}} 9.22,8.10,7.40\right.$ and 7.30$)$, with downfield chemical shifts in comparison with the aromatic proton signals of $\mathbf{3}$. These signals suggested a 6a-7-dehydro-aporphine structure, which displayed a three aromatic ring conjugation system. The other proton signals of 4 icluded a $\mathrm{N}^{+} \mathrm{Me}$ singlet $\left(\delta_{\mathrm{H}} 3.64\right.$ which integrated for 6 protons), an OMe singlet ( $\left.\delta_{\mathrm{H}} 3.99\right)$ and a methylene-methylene system $\left(\delta_{\mathrm{H}} 4.02\right.$ and 3.47). The correlations observed in the gHSQC and gHMBC spectra were in accordance with this kind of structure. ${ }^{19}$ The OMe group was positioned at C-2 $\left(\delta_{\mathrm{c}} 147.6\right)$ on the basis of HMBC and ROESY correlations. The structure of 4 was therefore the trifluoroacetate salt of the $6 \mathrm{a}, 7$-didehydro-1,9,10trihydroxy-2-methoxy-6-methyl aporphinium.

Gnetum is currently the only genus belonging to the family Gnetaceae. These gymnosperms have vessel elements in their xylem, which is a feature more commonly found in the angiosperms than in gymnosperms. Plants of this genus include trees, shrubs and lianas and are found in Africa, Asia as well as in Central and South America. The genus is a well known source of polyphenols, mainly stilbenoid derivatives. ${ }^{20}$ There are a small number of papers reporting the presence of alkaloids from this genus. To date, only ten alkaloids have been reported. ${ }^{21}$ Gnetum montanum is a vine which can reach more than $10 \mathrm{~m}$ in length. It can be found in the forests of the southern part of China, as well as in other South-Asian countries (Bhutan, India, Laos, Myanmar, Thailand and Vietnam). Fibres from the stem bark have been used for making bags, fishing nets, and ropes. The seeds produce an edible oil, and can also been eaten fried. ${ }^{22}$ This plant has been used as a traditional medicine in China to treat arthritis and bronchitis. The plant is a source of stilbenes, dimeric stilbenes, flavonoids and triterpenes. ${ }^{23}$

Table 3 shows the antibacterial activities against $P$. aeruginosa PAO1 and $S$. aureus 01A1095 for compounds 1-6. The activity of the reference antibiotic, ciprofloxacin is also reported. Compounds 3 and $\mathbf{4}$ displayed weak activities, while 1, 2, and $\mathbf{6}$ were not active. It is 
worth noting that both aporphine derivatives were slightly active, while the three benzylisoquinolines were inactive. Compound $\mathbf{5}$ showed promising inhibitory activity against $P$. aeruginosa PAO1, with minimal activity against $S$. aureus 01A1095, displaying a moderate selectivity for Pseudomonas, approximated at 36 times. Screening of 5 against other Gramnegative and positive species would be warranted to further determine Gram- selectivity.

\section{Experimental Section}

General Experimental Procedures. Optical rotations were measured on a Jasco P-1020 polarimeter (Jasco, Tokyo, Japan). UV spectra were recorded on a Jasco V650 UV/vis spectrophotometer. NMR spectra were recorded at $30{ }^{\circ} \mathrm{C}$ on either a Varian 500 or $600 \mathrm{MHz}$ Unity INOVA spectrometer (Varian, Walnut Creek, CA, USA). The latter spectrometer was equipped with a triple resonance cold probe. The ${ }^{1} \mathrm{H}$ and ${ }^{13} \mathrm{C}$ NMR chemical shifts were referenced to the solvent peaks for DMSO- $d_{6}$ at $\delta_{\mathrm{H}} 2.49$ and $\delta_{\mathrm{C}} 39.5$. LRESIMS were recorded on a Mariner Timeof-Flight spectrometer (Applied BioSystems, Foster City, CA, USA) equipped with a Gilson 215 eight probe injector (Waters, Milford, MA, USA). HRESIMS were recorded on a Bruker Daltronics Apex III 4.7e Fourier-transform mass spectrometer (Bruker, Karlsruhe, Germany). A BIOLINE orbital shaker (Edwards Instrument Company, Narellan, NSW, Australia) was used for the large-scale extraction of plant material. Machery Nagel Polyamide CC6 (0.05-0.016 mm) was used for tannin/polyphenolic removal (Machery Nagel, Düren, Germany). Alltech Davisil 40-60 $\mu \mathrm{m} 60 \AA \mathrm{C}_{18}$ bonded silica was used for preadsorption work (Alltech, Deerfield, IL, USA). A Waters 600 pump equipped with a Waters 996 PDA detector and a Waters 717 autosampler were used for HPLC. A Thermo-Electron $\mathrm{C}_{18}$ Betasil $143 \AA$ column $(5 \mu \mathrm{m}, 21.2 \times 150 \mathrm{~mm})$ (Thermo Scientific, Los Angeles, CA, USA) or a Phenomenex Luna $\mathrm{C}_{18}(5 \mu \mathrm{m}, 21.2 \times 250 \mathrm{~mm})$ (Phenomenex, Torrance, CA, USA) were used for semipreparative HPLC separations. All solvents 
used for chromatography, UV, and MS were Lab-Scan HPLC grade (RCI Lab-Scan, Bangkok, Thailand), and the $\mathrm{H}_{2} \mathrm{O}$ was Millipore Milli-Q PF filtered (Millipore, Billerica, MA, USA).

Plant Material. The leaves of Gnetum montanum Markgr. (Gnetaceae) were collected by the Zi Yuan Company in the Guangxi province, China, in January 2000 and a voucher sample (17JAN-2000:12:00_03101699C) is lodged with the Zi Yuan Medicine Company, China.

Extraction and Isolation. The dried and ground leaves of $G$. montanum (10 g) were transferred to a conical flask $(1 \mathrm{~L}), n$-hexane $(250 \mathrm{~mL})$ was added, and the flask was shaken at 200 rpm for $2 \mathrm{~h}$. The $n$-hexane extract was filtered under gravity, and then discarded. $\mathrm{CH}_{2} \mathrm{Cl}_{2}(250 \mathrm{~mL})$ was added to the defatted plant material in the conical flask and shaken at $200 \mathrm{rpm}$ for $2 \mathrm{~h}$. The resulting extract was filtered under gravity and set aside. $\mathrm{MeOH}(250 \mathrm{~mL})$ was added, and the $\mathrm{MeOH} /$ plant mixture was shaken for a further $2 \mathrm{~h}$ at $200 \mathrm{rpm}$. Following gravity filtration the plant material was extracted again with $\mathrm{MeOH}(250 \mathrm{~mL})$ while being shaken at $200 \mathrm{rpm}$ for $16 \mathrm{~h}$. All $\mathrm{CH}_{2} \mathrm{Cl}_{2} / \mathrm{MeOH}$ extracts were combined and dried under reduced pressure to yield a dark greenbrown solid (2.88 g). This material was resuspended in $\mathrm{MeOH}(150 \mathrm{~mL})$, loaded onto $\mathrm{MeOH}-$ conditioned polyamide gel (30 g) in a sintered glass column, and washed with $\mathrm{MeOH}(300 \mathrm{~mL})$ to yield $2.45 \mathrm{~g}$ of tannin-free extract. A portion of the this crude $(1 \mathrm{~g})$ was preadsorbed to $\mathrm{C}_{18}$-bonded silica, and then packed into a stainless steel cartridge $(10 \times 30 \mathrm{~mm})$ that was subsequently attached to a $\mathrm{C}_{18}$ Betasil HPLC column. Isocratic HPLC conditions of $90 \% \mathrm{H}_{2} \mathrm{O}(0.1 \% \mathrm{TFA}) / 10 \% \mathrm{MeOH}$ $(0.1 \%$ TFA $)$ were initially employed for $10 \mathrm{~min}$, then a linear gradient to $100 \% \mathrm{MeOH}(0.1 \% \mathrm{TFA})$ was run over $40 \mathrm{~min}$, followed by isocratic conditions of $100 \% \mathrm{MeOH}(0.1 \% \mathrm{TFA})$ for a further $10 \mathrm{~min}$, all at a flow rate of $9 \mathrm{~mL} / \mathrm{min}$. Sixty fractions $(60 \times 1 \mathrm{~min})$ were collected from time $=0$ min, then analysed by (+)-LRESIMS. Fraction 18 afforded $9.8 \mathrm{mg}$ of $\mathbf{1}(0.24 \%$ dry wt). Fraction 20 was purified by HPLC using the same Betasil column as before, and a gradient of $\mathrm{H}_{2} \mathrm{O}(0.1 \%$ TFA) / $\mathrm{MeOH}(0.1 \%$ TFA) (80:20 to 50:50 in 60 minutes) to yield $7.2 \mathrm{mg}$ of $2(0.17 \%$ dry wt). Compound 5 (3.6 mg, $0.09 \%$ dry wt) was obtained by separating fraction 21 by HPLC with a 
Phenomenex Luna $\mathrm{C}_{18}$ column using a gradient of $\mathrm{H}_{2} \mathrm{O}(0.1 \%$ TFA) / MeOH (0.1\% TFA) (80:20 to $50: 50$ in 30 minutes). Fraction 26 was purified by HPLC using the same Phenomenex Luna $\mathrm{C}_{18}$ column as before, and a gradient of $\mathrm{H}_{2} \mathrm{O}(0.1 \%$ TFA) / $\mathrm{MeOH}(0.1 \%$ TFA) (70:30 to 50:50 in 30 minutes $)$ to yield $1.3 \mathrm{mg}$ of $4(0.03 \%$ dry wt). Finally, fraction 22 was separated with the Phenomenex Luna $\mathrm{C}_{18}$ column using a gradient of $\mathrm{H}_{2} \mathrm{O}(0.1 \%$ TFA) / $\mathrm{MeOH}(0.1 \%$ TFA) (70:30 to $50: 50$ in 30 minutes $)$. Thirty fractions $(30 \times 1 \mathrm{~min})$ were collected from time $=0 \mathrm{~min}$, then analysed by (+)-LRESIMS. Fraction 21 afforded $6.3 \mathrm{mg}$ of 3 ( $0.15 \%$ dry wt), while fraction 23 yielded $6.4 \mathrm{mg}$ of $6(0.15 \%$ dry wt).

P. aeruginosa optical density $\left(\mathbf{O D}_{620}\right)$ viability assay. P.aeruginosa $\mathrm{PAO} 1$ or PAO200 strain (supplied by Pfizer Global Research and Development) cultures were prepared at $3.5 \times 10^{4}$ $\mathrm{CFU} / \mathrm{mL}$ in cation-adjusted Mueller Hinton (caMH) broth (Difco, Detroit, MI, USA), from concentrated frozen stocks of culture. The final bacterial concentration in the assay was 1500 CFU/well. $45 \mu \mathrm{L}$ of diluted bacteria was added to a 384 well lidded, sterile clear plate (Becton Dickinson, Franklin Lakes, NJ, USA) containing controls/fractions by a Multidrop ${ }^{\mathrm{TM}}$ liquid handler (Thermo Scientific, Barrington, USA). Plates were incubated at $37^{\circ} \mathrm{C}$ in a humidified incubator for 18 hours or until the wells reached an optical density $\left(\mathrm{OD}_{620}\right)$ of between $0.7-0.8$, then allowed to cool for 30 minutes. Clear plate seals (Perkin Elmer, Meriden CT, USA) were placed over the plate surface before reading on a Multiskan Ascent reader (Thermo Scientific) at $620 \mathrm{~nm}$.

Prior to addition of bacteria a $5 \mu \mathrm{L}$ addition of either test fractions, compounds or control samples were added to the assay plate. Samples were prepared by dilution of stock fractions/compounds/controls in $100 \%$ DMSO in to the assay plate with addition of $0.875 \mu \mathrm{L}$ of stock and 4.125 $\mu \mathrm{L}$ of autoclaved Milli-Q filtered water with a Minitrak ${ }^{\mathrm{TM}}$ (Perkin Elmer, Meriden CT, USA) liquid handler. The final concentration of DMSO in the assay was $1.75 \%$. Each assay plate contained both positive and negative controls in columns 23 and 24 respectively. The positive 
control, for uninhibited growth, consisted of $5 \mu \mathrm{L}$ of DMSO/milli-Q water to a final concentration of $1.75 \%$ and the negative control, or $100 \%$ cell death, was comprised of $5 \mu \mathrm{L}$ of the broad spectrum antibiotic ciprofloxacin (Sigma-Aldrich, St Louis, MO, USA) at a final concentration of $5 \mu \mathrm{g} / \mathrm{mL}$. Whole control plates were included for each assay run, which consisted of duplicate dose response curves of ciprofloxacin, each in triplicate.

S.aureus optical density viability assay. The S.aureus assay was carried out as per P.aeruginosa assay, with the following modifications: the final bacterial concentration used was $1980 \mathrm{CFU} /$ well and ciprofloxacin for the internal assay control wells was at $500 \mu \mathrm{g} / \mathrm{mL}$. Incubation was for 19 hours, or until the $\mathrm{OD}_{620}$ reached 0.45

$N$-methyl-laudanosolinium trifluoroacetate (1). Brown gum; $[\alpha]_{D}^{24} 10.3(\mathrm{MeOH}, c$ 0.1); UV (MeOH) $\lambda_{\max }(\log \varepsilon) 233 \mathrm{sh}(3.19), 287$ (2.99); ${ }^{1} \mathrm{H}$ and ${ }^{13} \mathrm{C}$ see Table 1; (+)-HRESIMS: $m / z$ $316.15437\left(\mathrm{C}_{18} \mathrm{H}_{22} \mathrm{NO}_{4}:[\mathrm{M}]^{+}\right.$, requires 316.15434$)$

3'-hydroxy- $\boldsymbol{N}, \boldsymbol{N}$-dimethyl coclaurinium trifluoroacetate (2). Brown gum; $[\alpha]_{D}^{25} 14.5$ $\left(\mathrm{MeOH}, c\right.$ 0.1); UV (MeOH) $\lambda_{\max }(\log \varepsilon) 231 \mathrm{sh}(3.52), 286(3.29) ;{ }^{1} \mathrm{H}$ and ${ }^{13} \mathrm{C}$ see Table 1; (+)HRESIMS: $m / z 330.16914\left(\mathrm{C}_{19} \mathrm{H}_{24} \mathrm{NO}_{4}:[\mathrm{M}]^{+}\right.$, requires 330.16999)

1,9,10-trihydroxy-2-methoxy-6-methyl aporphinium trifluoroacetate (3). Brown gum; $[\alpha]_{D}^{24} 8.3\left(\mathrm{MeOH}, c\right.$ 0.1); UV (MeOH) $\lambda_{\max }(\log \varepsilon) 229$ (3.80), $270 \mathrm{sh}$ (3.28), 281 (3.33), 308 (3.42), $317 \mathrm{sh}(3.39) ;{ }^{1} \mathrm{H}$ and ${ }^{13} \mathrm{C}$ see Table 2; (+)-HRESIMS: $m / z 328.15320\left(\mathrm{C}_{19} \mathrm{H}_{22} \mathrm{NO}_{4}\right.$ : $[\mathrm{M}]^{+}$, requires 328.15434)

6a,7-didehydro-1,9,10-trihydroxy-2-methoxy-6-methyl aporphinium trifluoroacetate (4). Brown gum; UV (MeOH) $\lambda_{\max }(\log \varepsilon) 222 \mathrm{sh}$ (3.74), 270 (3.88), $288 \mathrm{sh}$ (3.67), 335 (3.35), 353 (3.33), 371 (3.32); ${ }^{1} \mathrm{H}$ and ${ }^{13} \mathrm{C}$ see Table 1; (+)-HRESIMS: $m / z \quad 326.13819\left(\mathrm{C}_{19} \mathrm{H}_{20} \mathrm{NO}_{4}\right.$ : $[\mathrm{M}]^{+}$, requires 326.13869$)$ 


\section{Acknowledgements}

The authors would like to acknowledge Pfizer Global Research and Development for financial support. We thank Alita Miller, Doug Fisher and Justin Montgomery at Pfizer Global Research and Development for advice during the screening and isolation campaign. The authors thank C. Lewis and K. Watts from the Molecular Libraries group (Eskitis Institute), for their assistance in the preparation of the screening library. We also thank $\mathrm{H}$. Vu from Griffith University for acquiring the HRESIMS measurements.

Supporting Information Available: ${ }^{1} \mathrm{H}$ and ${ }^{13} \mathrm{C}$ NMR spectrum of compounds 1-3, ${ }^{1} \mathrm{H}$ and 2D NMR spectrum of compound 4. This material is available free of charge via the Internet at http://pubs.acs.org. 


\section{References and Notes}

(1) McGowan, J. E., Jr., Am. J. Infect. Control 2006, 34, S29-37; discussion S64-73.

(2) Quinn, J. P., Clin. Infect. Dis. 1998, 27 Suppl 1, S117-24.

(3) Higgins, C. F., Nature 2007, 446, 749-57.

(4) Zgurskaya, H. I.; Nikaido, H., Mol. Microbiol. 2000, 37, 219-25.

(5) Hancock, R. E., Clin. Infect. Dis. 1998, 27 Suppl 1, S93-9.

(6) Leibovici, L.; Vidal, L.; Paul, M., J. Antimicrob. Chemother. 2009, 63, 246-51.

(7) Pelaez, F., Biochem. Pharmacol. 2006, 71, 981-90.

(8) Lee, S.-S.; Lin, Y.-J.; Chen, C.-K.; Liu, K. C. S.; Chen, C.-H., J. Nat. Prod. 1993, 56, 19711976.

(9) Rochfort, S. J.; Towerzey, L.; Carroll, A.; King, G.; Michael, A.; Pierens, G.; Rali, T.; Redburn, J.; Whitmore, J.; Quinn, R. J., J. Nat. Prod. 2005, 68, 1080-1082.

(10) Zhao, Q.; Zhao, Y.; Wang, K., J. Ethnopharmacol. 2006, 106, 408-413.

(11) Brossi, A.; Ramel, A.; O'Brien, J.; Teitel, S., Chem. Pharm. Bull. 1973, 21, 1839-40.

(12) Gözler, B.; Kivçak, B.; Gözler, T.; Shamma, M., J. Nat. Prod. 1990, 53, 666-668.

(13) Meyers, A. I.; Dickman, D. A.; Boes, M., Tetrahedron 1987, 43, 5095-108.

(14) Lee, S.-S.; Doskotch, R. W., J. Nat. Prod. 1999, 62, 803-810.

(15) Kametani, T.; Noguchi, I., J. Chem. Soc. C 1967, 1440-3.

(16) Lee, S.-S.; Lai, Y.-C.; Chen, C.-K.; Tseng, L.-H.; Wang, C.-Y., J. Nat. Prod. 2007, 70, 637642.

(17) Iturriaga-Vásquez, P.; Pérez, E. G.; Slater, E. Y.; Bermúdez, I.; Cassels, B. K., Bioorg. Med. Chem. 2007, 15, 3368-3372.

(18) Ringdahl, B.; Chan, R. P. K.; Craig, C.; Cava, M. P.; Shamma, M., J. Nat. Prod. 1981, 44, 80-85. 
(19) Daskalova, E.; Iskrenova, E.; Kiryakov, H. G.; Evstatieva, L., Phytochemistry 1988, 27, 953955.

(20) Ali, Z.; Tanaka, T.; Iliya, I.; Iinuma, M.; Furusawa, M.; Ito, T.; Nakaya, K.-i.; Murata, J.; Darnaedi, D., J. Nat. Prod. 2003, 66, 558-560.

(21) Dictionary of Natural Products on CD-Rom, 18.1; Chapman and Hall/CRC Press: London, UK, 2009.

(22) Fu, L.; Yu, Y.-F.; Gilbert, M. G., Gnetaceae. In Flora of China, Science Press (Beijing) \& Missouri Botanical Garden (St. Louis): 1999; Vol. 4, pp 102-105.

(23) Xiang, W.; Jiang, B.; Li, X.-M.; Zhang, H.-J.; Zhao, Q.-S.; Li, S.-H.; Sun, H.-D., Fitoterapia 2002, 73, 40-42. 

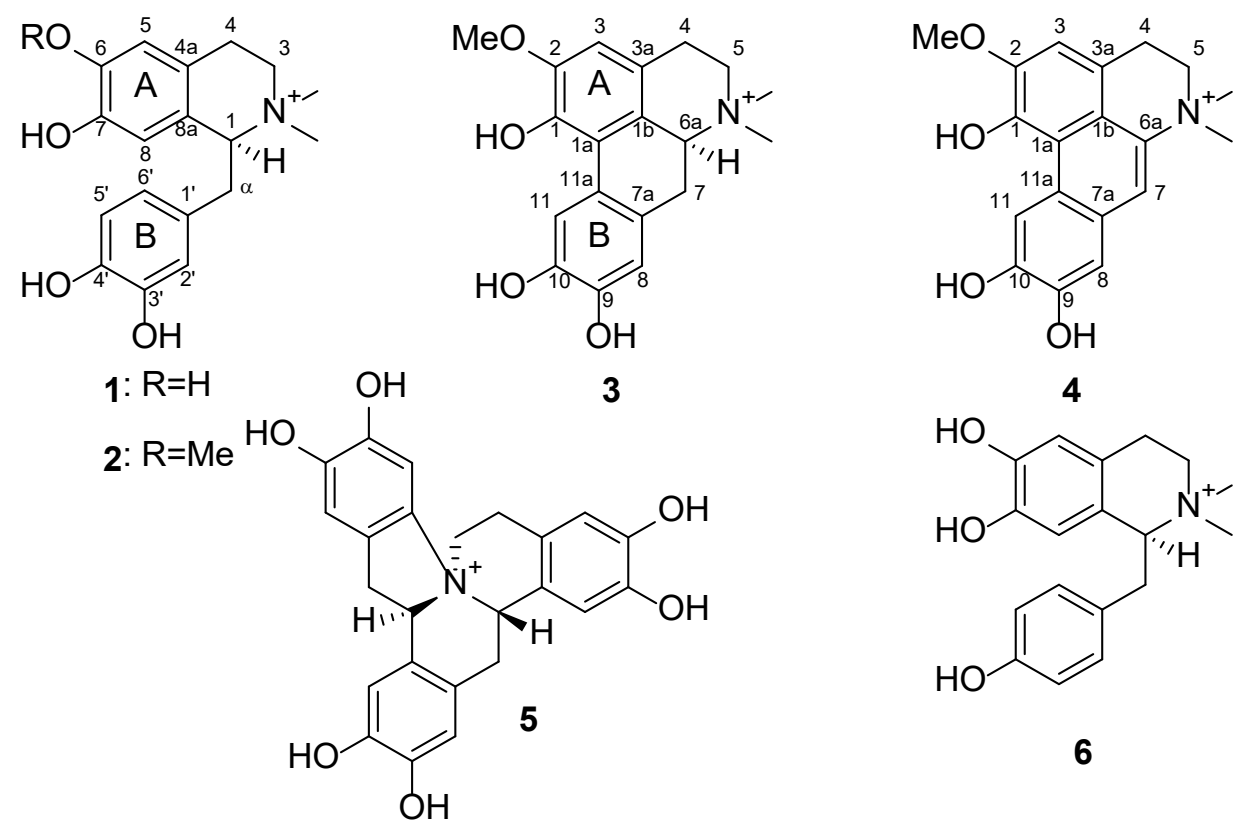


\section{Table 1}

NMR data for compounds $\mathbf{1}$ and $\mathbf{2}^{*}$

\begin{tabular}{|c|c|c|c|c|}
\hline \multirow[b]{2}{*}{ position } & \multicolumn{2}{|r|}{1} & \multicolumn{2}{|r|}{2} \\
\hline & $\delta_{\mathrm{C}}$, mult & $\delta_{\mathrm{H}}$, mult $(J$ in $\mathrm{Hz})$ & $\delta_{\mathrm{C}}$ & $\delta_{\mathrm{H}}$, mult $(J$ in $\mathrm{Hz})$ \\
\hline 1 & $71.3, \mathrm{CH}$ & $4.55 \mathrm{dd}(9.1,2.9)$ & 71.2 & $4.59 \mathrm{dd}(9.1,2.6)$ \\
\hline 3 & $54.3, \mathrm{CH}_{2}$ & $\begin{array}{l}\text { a } 3.68 \mathrm{~m} \\
\text { b } 3.54 \mathrm{~m}\end{array}$ & 54.3 & $\begin{array}{l}\text { a } 3.71 \mathrm{~m} \\
\text { b } 3.58 \mathrm{~m}\end{array}$ \\
\hline 4 & $22.4, \mathrm{CH}_{2}$ & $2.97 \mathrm{~m}$ & 23.8 & $3.05 \mathrm{~m}$ \\
\hline $4 a$ & $118.9, \mathrm{C}$ & & 119.2 & \\
\hline 5 & 114.7, CH & $6.58 \mathrm{~s}$ & 113.3 & 6.79 \\
\hline 6 & 143.6, C & & 147.7 & \\
\hline $6-\mathrm{OH}$ & & $8.84^{a}$ & & \\
\hline 7 & $145.5, \mathrm{C}$ & & 145.5 & \\
\hline 7-OH & & $9.11^{a}$ & & 8.89 \\
\hline 8 & $114.5, \mathrm{CH}$ & $5.94 \mathrm{~s}$ & 114.5 & 5.95 \\
\hline $8 \mathrm{a}$ & $121.6, \mathrm{C}$ & & 123.3 & \\
\hline$\alpha$ & $35.6, \mathrm{CH}_{2}$ & $\begin{array}{l}\text { a } 3.44 \mathrm{dd}(13.9,3.1) \\
\text { b } 2.68 \mathrm{dd}(13.9,9.4)\end{array}$ & 36.4 & $\begin{array}{l}\text { a } 3.46 \mathrm{dd}(13.9,2.8) \\
\text { b } 2.68 \mathrm{dd}(13.9,9.3)\end{array}$ \\
\hline $1^{\prime}$ & $127.7, \mathrm{C}$ & & 127.0 & \\
\hline $2^{\prime}$ & 116.6, CH & $6.53 \mathrm{~d}(1.9)$ & 116.5 & $6.52 \mathrm{~d}(1.5)$ \\
\hline $3^{\prime}$ & $145.2, \mathrm{C}$ & & 145.7 & \\
\hline 3'-OH & & $8.77^{b}$ & & $8.75^{c}$ \\
\hline $4^{\prime}$ & 144.1, C & & 143.9 & \\
\hline $4^{\prime}-\mathrm{OH}$ & & $8.92^{b}$ & & $8.91^{c}$ \\
\hline $5^{\prime}$ & $115.2, \mathrm{CH}$ & $6.65 \mathrm{~d}(8.0)$ & 115.2 & $6.65 \mathrm{~d}(8.0)$ \\
\hline $6^{\prime}$ & $119.9, \mathrm{CH}$ & $6.35 \mathrm{dd}(8,1.9)$ & 119.9 & $6.35 \mathrm{dd}(8.0,1.5)$ \\
\hline $\begin{array}{l}-\mathrm{N}^{+} \mathrm{Me}_{2} \\
-\mathrm{OMe}\end{array}$ & $\begin{array}{l}50.2, \mathrm{CH}_{3} \\
50.0, \mathrm{CH}_{3}\end{array}$ & $\begin{array}{l}3.23 \mathrm{~s} \\
3.03 \mathrm{~s}\end{array}$ & $\begin{array}{l}50.3 \\
50.0 \\
55.1\end{array}$ & $\begin{array}{l}3.25 \mathrm{~s} \\
3.04 \mathrm{~s} \\
3.75 \mathrm{~s}\end{array}$ \\
\hline
\end{tabular}


Table 2

NMR data for compounds 3 and $\mathbf{4}^{*}$

\begin{tabular}{|c|c|c|c|c|}
\hline \multirow[b]{2}{*}{ position } & \multicolumn{2}{|r|}{$\overline{3}$} & \multicolumn{2}{|r|}{$\overline{4}$} \\
\hline & $\delta_{\mathrm{C}}$, mult & $\delta_{\mathrm{H}}$, mult $(J$ in $\mathrm{Hz})$ & $\delta_{\mathrm{C}}$, mult & $\delta_{\mathrm{H}}$, mult $(J$ in $\mathrm{Hz})$ \\
\hline 1 & $142.1, \mathrm{C}$ & & $142.9, \mathrm{C}$ & \\
\hline $1-\mathrm{OH}$ & & $a$ & & 9.74 \\
\hline $1 \mathrm{a}$ & $120.4, \mathrm{C}$ & & $124.3, \mathrm{C}$ & \\
\hline $1 b$ & $119.5, \mathrm{C}$ & & 115.3, C & \\
\hline 2 & $148.1, \mathrm{C}$ & & 147.6, C & \\
\hline 3 & 109.0, CH & $6.78 \mathrm{~s}$ & $111.3, \mathrm{CH}$ & $7.40 \mathrm{~s}$ \\
\hline $3 a$ & $119.1, \mathrm{C}$ & & $118.8, \mathrm{C}$ & \\
\hline 4 & $23.1, \mathrm{CH}_{2}$ & $\begin{array}{l}\text { a } 3.18 \mathrm{~m} \\
\text { b } 2.93 \mathrm{~m}\end{array}$ & 23.7, $\mathrm{CH}_{2}$ & $3.47 \mathrm{t}(5.9)$ \\
\hline 5 & $60.4, \mathrm{CH}_{2}$ & $\begin{array}{l}\text { a } 3.74 \mathrm{~m} \\
\text { b } 3.65 \mathrm{td}(12.6,4.3)\end{array}$ & $60.9, \mathrm{CH}_{2}$ & $4.02, \mathrm{t}(5.9)$ \\
\hline $6 a$ & $68.3, \mathrm{CH}$ & $4.56 \mathrm{dd}(13.7,2.3)$ & 135.7, C & \\
\hline 7 & $28.1, \mathrm{CH}_{2}$ & $\begin{array}{l}\text { a } 3.16 \mathrm{~m} \\
\text { b } 2.73 \mathrm{t}(13.7)\end{array}$ & $116.3, \mathrm{CH}$ & $8.10, \mathrm{~s}$ \\
\hline $7 \mathrm{a}$ & $123.4, \mathrm{C}$ & & 119.3, C & \\
\hline 8 & $114.9, \mathrm{CH}$ & $6.71 \mathrm{~s}$ & $112.7, \mathrm{CH}$ & $7.30, \mathrm{~s}$ \\
\hline 9 & $144.6, \mathrm{C}$ & & $143.8, \mathrm{C}$ & \\
\hline 9-OH & & $a$ & & $9.73^{b}$ \\
\hline 10 & $143.7, \mathrm{C}$ & & $146.5, \mathrm{C}$ & \\
\hline $10-\mathrm{OH}$ & & $a$ & & $9.58^{b}$ \\
\hline 11 & $116.3, \mathrm{CH}$ & $7.85 \mathrm{~s}$ & 113.6, $\mathrm{CH}$ & $9.22 \mathrm{~s}$ \\
\hline $11 \mathrm{a}$ & $122.5, \mathrm{C}$ & & 124.1, C & \\
\hline$-\mathrm{N}^{+} \mathrm{Me}_{2}$ & $\begin{array}{l}52.9, \mathrm{CH}_{3} \\
42.8, \mathrm{CH}_{3}\end{array}$ & $\begin{array}{l}3.34 \mathrm{~s} \\
2.93 \mathrm{~s}\end{array}$ & $54.5,2 \mathrm{xCH}_{3}$ & $3.64 \mathrm{~s}$ \\
\hline$-\mathrm{OMe}$ & $55.9, \mathrm{CH}_{3}$ & $3.85 \mathrm{~s}$ & $56.4, \mathrm{CH}_{3}$ & $3.99 \mathrm{~s}$ \\
\hline
\end{tabular}


Table 3

Antibacterial Activities for Compounds 1-6

\begin{tabular}{ccc}
\hline \hline & \multicolumn{2}{c}{$\mathrm{IC}_{50}(\mu \mathrm{M})$} \\
\cline { 2 - 3 } compound & P. aeruginosa PAO1 & S. aureus $01 \mathrm{~A} 1095$ \\
\hline $\mathbf{1}$ & $\mathrm{NA}$ & $\mathrm{NA}$ \\
$\mathbf{2}$ & $\mathrm{NA}$ & $\mathrm{NA}$ \\
$\mathbf{3}$ & $59 \% \% \pm 5.5 @ 175 \mu \mathrm{M}$ & $\mathrm{NA}$ \\
$\mathbf{4}$ & $59 \% \pm 0.6 @ 87.5 \mu \mathrm{M}$ & $\mathrm{NA}$ \\
$\mathbf{5}$ & $9.8 \pm 0.78 \mu \mathrm{M}$ & $55 \% \pm 2 @ 350 \mu \mathrm{M}$ \\
$\mathbf{6}$ & $\mathrm{NA}$ & $\mathrm{NA}$ \\
Cip & $0.038 \pm 0.01 \mu \mathrm{M}$ & $124.65 \pm 19.78 \mu \mathrm{M}$
\end{tabular}

NA not active at a screening dose of $350 \mu \mathrm{M}$ 
TOC

Alkaloids from the Chinese Vine Gnetum montanum
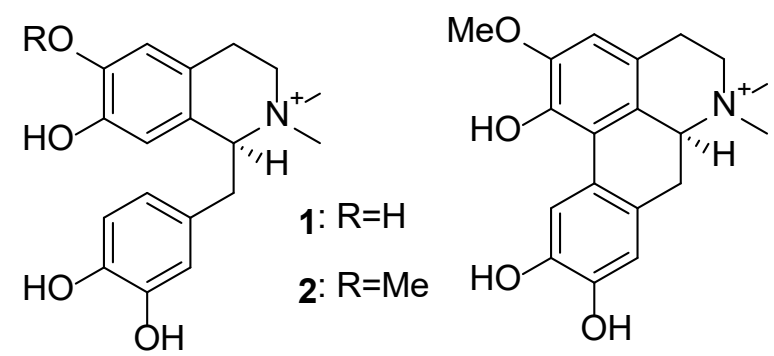<smiles>COc1cc2c3c4c(c(O)c(O)cc14)-c1cc(O)c(O)cc1C=C3[N+](C)(C)CC2</smiles>

3

4 